\title{
Uptake of diatoms in Baltic Sea macrozoobenthos during short-term exposure to severe and moderate hypoxia
}

\author{
Gunilla Ejdung ${ }^{1, *}$, Lars Byrén ${ }^{1}$, Ann-Kristin Eriksson Wiklund ${ }^{2}$, Brita Sundelin ${ }^{2}$ \\ ${ }^{1}$ Department of Systems Ecology, and ${ }^{2}$ Department of Applied Environmental Science, Stockholm University, \\ 10691 Stockholm, Sweden
}

\begin{abstract}
The effect of severe and moderate hypoxia on food uptake of benthic macrofauna was studied in the laboratory. The hypothesis was that low oxygen concentrations negatively affect feeding at oxygen levels that have little effect on the studied animals' survival. The bivalve Macoma balthica, the priapulid Halicryptus spinulosus, the amphipods Monoporeia affinis (subadult \& juvenile) and Pontoporeia femorata (subadult) were offered the ${ }^{14} \mathrm{C}$-labelled diatom Skeletonema costatum in 0.8 to $10.6 \mathrm{mg} \mathrm{O}_{2} \mathrm{l}^{-1}$. Feeding was measured as radioactivity uptake. Subadult amphipods were studied one species at a time (single) or together (mixed). Feeding changed in all amphipods at the lowest oxygen concentrations, but no effect was found for $M$. balthica and $H$. spinulosus. At the lowest concentration $\left(0.8 \mathrm{mg} \mathrm{O}_{2} \mathrm{l}^{-1}\right.$ ) feeding by subadult $M$. affinis (single) was only $17 \%$ of the full oxygen saturation (10.6 $\left.\mathrm{mg} \mathrm{O}_{2} \mathrm{l}^{-1}\right)$, and, at $1.6 \mathrm{mg} \mathrm{O}_{2} \mathrm{l}^{-1}, 14 \%$ of the feeding at $8.9 \mathrm{mg} \mathrm{O}_{2} \mathrm{l}^{-1}$. Juvenile $M$. affinis consumed more labelled algae at $3 \mathrm{mg} \mathrm{O} \mathrm{O}^{-1}$ than at higher oxygen concentrations. $M$. balthica feeding was not affected. Little radioactivity uptake was registered for $H$. spinulosus at any oxygen concentration, showing that $H$. spinulosus is not a surface deposit feeder. The amphipods were the most sensitive to week-long oxygen deficiency. Survival decreased significantly in the lowest oxygen concentrations $\left(0.8 ; 1.6 \mathrm{mg} \mathrm{O}_{2} \mathrm{l}^{-1}\right)$. Of the subadult $M$. affinis 15 and $65 \%$, respectively, survived, compared with 0 and $58 \%$ for $P$. femorata. Juvenile $M$. affinis mortality was high in all oxygen concentrations, whereas most $M$. balthica and $H$. spinulosus survived.
\end{abstract}

KEY WORDS: Severe hypoxia $\cdot$ Moderate hypoxia $\cdot$ Macrobenthos $\cdot{ }^{14} \mathrm{C}$-uptake $\cdot$ Baltic Sea Resale or republication not permitted without written consent of the publisher

\section{INTRODUCTION}

In recent decades, episodes of anoxia and hypoxia have become more frequent, and the affected areas have expanded in many aquatic ecosystems throughout the world (Diaz \& Rosenberg 1995, Gray et al. 2002, Karlson et al. 2002). Low oxygen concentrations may occur naturally under conditions of vertical stratification, but oxygen depletion is often caused or aggravated by human activities via anthropogenic supply of nutrients and organic matter (Levin et al. 2001, Gray et al. 2002). In general, oxygen deficiency in deep areas tends to be more or less permanent (Levin 2002), whereas in shallower areas it is mostly irregular and episodic or periodic and seasonal (Gray et al. 2002, Karlson et al. 2002). Anoxic and hypoxic bottom areas develop gradually (Diaz \& Rosenberg 1995), e.g. stratified water masses and drifting algal mats can cause short-term hypoxia (days to weeks).

Poor oxygen conditions may affect population dynamics, diversity, abundance and the functional and structural composition of benthic communities (Elmgren 1978, Diaz \& Rosenberg 1995). Severe oxygen conditions reduce populations or even eliminate taxa (Savage et al. 2002), as animals die (Diaz \& Rosenberg 1995) or flee from affected areas (Hagerman \& Uglow 1982). Activity, burrowing and depth distribution of macrobenthic animals in the sediment decrease under poor oxygen conditions (Johansson 1997a, Tallqvist 2001). Further, reproductive success, somatic growth and predator-prey interactions, such as prey handling times, are also affected by oxygen conditions (Sand- 
berg 1994, Brante \& Hughes 2001, Eriksson Wiklund \& Sundelin 2001). Feeding by macrobenthos under poor oxygen conditions has been reported as weight loss of food available (Das \& Stickle 1993), estimated from prey survival data (Sandberg 1994), or given as clearance rate (Sobral \& Widdows 1997). The effect of low, but not lethal, oxygen concentrations on feeding activity in macrobenthos is poorly known, but has been recorded accurately in flowing and flushed seawater by Maire et al. (2006). Food uptake can be studied using uptake of food labelled with radioactive and/or stable isotopes (Ejdung et al. 2000, Byrén et al. 2002, 2006).

In the Baltic Sea, one of the world's largest brackish water areas (ca. $373000 \mathrm{~km}^{2}$ ), large bottom areas (70000 to $100000 \mathrm{~km}^{2}$ ) suffer intermittent oxygen depletion (Karlson et al. 2002). The extension of areas with lethal or sublethal oxygen conditions varies seasonally and between years (Jansson \& Dahlberg 1999). The oxygen conditions affect the composition of the benthic macrofauna, which is periodically absent below $80 \mathrm{~m}$ depth (Elmgren 1978). Generally, the diversity below the thermocline in the northern Baltic proper, central Baltic Sea, is low, with 6 to 7 species of benthic macrofauna (Elmgren 1978). Here, the amphipods Monoporeia affinis (Lindström) and Pontoporeia femorata Kröyer and the bivalve Macoma balthica (L.) have dominated in abundance and biomass for many years (Laine et al. 1997, Ejdung \& Elmgren 2001). In some areas, the 2 amphipod species co-occur, in other areas only 1 of the species is found. Their distribution is related to their respective freshwater $(M$. affinis) or marine origin ( $P$. femorata) and to Baltic Sea salinity conditions (Segerstråle 1950). The priapulid Halicryptus spinulosus (von Siebold) has periodically been absent from areas in the northern Baltic proper, but, since the beginning of the 1990s, its abundance and biomass has increased (Laine et al. 1997).

Adult Macoma balthica are facultative deposit and suspension feeders (Ólafsson 1986) that are resistant to moderate hypoxia conditions, which they can survive in for months at temperatures $<5^{\circ} \mathrm{C}$ (Dries \& Theede 1974, Karlson et al. 2002). Halicryptus spinulosus is a facultative anaerobe that survives long periods of total anoxia (Oeschger \& Storey 1990, Diaz \& Rosenberg 1995). This arctic-boreal species is regularly exposed to low oxygen levels, particularly in organically enriched areas, as it burrows down to at least $30 \mathrm{~cm}$ depth in the sediment (Oeschger et al. 1992). The burrow system has openings at the sediment surface, and new openings are made during periods of poor oxygen conditions (Powilleit et al. 1994). H. spinulosus has been found on the sediment surface after exposure to anoxia (Oeschger 1990). Although reported to be a predator, its gut commonly contains detritus (Ankar \&
Sigvaldadottir 1981), and it has also been characterised as a sub-surface deposit feeder (Arntz 1978). Whether H. spinulosus feeds under hypoxic conditions (Oeschger 1990), and whether it is a surface deposit feeder has not been studied earlier.

Our objective was to study the effect of severe and moderate hypoxia on the foraging of benthic macrofauna. We tested the hypothesis that low oxygen concentrations reduce feeding by benthic macrofauna even at oxygen levels that have little effect on survival of the studied animals. To our knowledge this is the first study in which the effect of oxygen deficiency on feeding by deposit feeders of various phyla has been monitored with radioactively $\left({ }^{14} \mathrm{C}\right)$ labelled diatoms.

\section{MATERIALS AND METHODS}

The uptake of radioactivity from ${ }^{14} \mathrm{C}$-labelled diatoms deposited on the sediment surface by Macoma balthica, Halicryptus spinulosus, juvenile and subadult Monoporeia affinis, and subadult Pontoporeia femorata, and a mixture of subadult $M$. affinis and subadult $P$. femorata was studied in the laboratory under moderate and severe hypoxia ( $\mathrm{MH}$ and $\mathrm{SH}$, respectively). The measured radioactivity uptake includes assimilated radioactivity, the radioactivity remaining in the gut of the animals, and radioactivity adsorbed on the outer body surface, e.g. by bacterial growth. The radioactive signal can be found after a week (Ejdung et al. 2000), and the experiments were performed for $7 \mathrm{~d}$ in July 1998 and in June 1999 at the Department of Systems Ecology, Stockholm University (SU), Stockholm, Sweden, and at the Studsvik Laboratory, Department of Applied Environmental Science, SU, Sweden.

Collection of animals and culturing of algae. Sediment and animals were collected with a benthic sled from 30 to $40 \mathrm{~m}$ depth in the Askö area $\left(58^{\circ} 49^{\prime} \mathrm{N}\right.$, $\left.17^{\circ} 38^{\prime} \mathrm{E}\right)$, north-western Baltic proper. We use the natural animal size distribution that occurred in the investigation area at the time when the experiments were conducted, and size is given as dry mass for the subadult amphipods, Halicryptus spinulosus and Macoma balthica. Sieving the sediment through a $0.5 \mathrm{~mm}$ sieve removed all macrofauna. Before use, the animals of the $\mathrm{MH}$ experiments were kept at $5^{\circ} \mathrm{C}$ in natural sediment and seawater, and in natural sediment and artificial seawater for the $\mathrm{SH}$ experiments, i.e. conditions were similar to those in the experiments. We define $\mathrm{MH}$ as oxygen concentrations ranging from $\geq 2$ to $6 \mathrm{mg} \mathrm{O}_{2} \mathrm{l}^{-1}$ and $\mathrm{SH}$ as $<2 \mathrm{mg} \mathrm{O}_{2} \mathrm{l}^{-1}$. Artificial seawater was prepared by adding commercial aquarium sea salt (HW-Marinemix + Bioelements, Wiegandt $\mathrm{GmbH}$ ) to tap water, to a salinity of 6.5 , approximately the natural salinity at $40 \mathrm{~m}$ depth in the Askö area. The 
artificial seawater was used when natural water was not available ( $\mathrm{SH}$ experiment). A daily light cycle of $16 \mathrm{~h}$ light:8 $\mathrm{h}$ dark and a temperature of $5^{\circ} \mathrm{C}$ were maintained during storage and experiments.

The diatom Skeletonema costatum (Greville), often a dominant spring bloom species in the study area (Hobro 1979), was used as food. It contains high levels of polyunsaturated fatty acids, which have been reported as high-quality food resources for growth (Goedkoop et al. 2000). S. costatum was cultured for $11 \mathrm{~d}$ in artificial seawater (salinity 15), prepared with $\mathrm{NaH}^{14} \mathrm{CO}_{3}$ (Kester et al. 1967, Byrén et al. 2002), then harvested and rinsed by centrifuging $3 \times 10 \mathrm{~min}$ at $\sim 350 \times g$ to remove dissolved ${ }^{14} \mathrm{C}$. The radioactivity of the algal batches, measured directly after harvesting, was $6.7 \times 10^{5} \mathrm{dpm} \mathrm{ml^{-1 }}(\mathrm{dpm}=$ disintegrations per minute; Batch a1), and $2.7 \times 10^{6} \mathrm{dpm} \mathrm{ml}^{-1}$ (Batch aa).

Before starting the experiments, we examined all animals under a stereomicroscope and replaced damaged individuals. At the end of the experiments, animals were sieved out from the sediment and counted. The subadult amphipods were placed in water-filled jars for $24 \mathrm{~h}$ to empty their gut. All animals were thoroughly rinsed in seawater before they were dried. The dry mass of subadult amphipods and Halicryptus spinulosus and the soft parts of Macoma balthica were determined. As ingestion rates scale allometrically to body size (Peters 1983), we have chosen to show the radioactivity uptake as disintegrations per minute per milligram dry mass ${ }^{0.75}$ for the subadult amphipods, $M$. balthica and $H$. spinulosus. The weighed subadult amphipods, $M$. balthica and $H$. spinulosus (1 specimen $\mathrm{jar}^{-1}$ ), and 13 to 40 juvenile Monoporeia affinis $\mathrm{jar}^{-1}$ were transferred to scintillation vials, and solubilised in $1 \mathrm{ml}$ Lumasolve (Lumac). Thereafter, $10 \mathrm{ml}$ scintillation cocktail (Hionic-Fluor, Packard) was added, and samples were counted in a liquid scintillation counter (LKB, 1214 RackBeta 'Excel', LKB Wallac).

Experiments and experimental design. Moderate hypoxia: The aim is to study feeding by Macoma balthica, Halicryptus spinulosus and juvenile Monoporeia affinis at $\mathrm{MH}$ of 3 and $6 \mathrm{mg} \mathrm{O} \mathrm{O}^{-1}$, with the control at $10 \mathrm{mg} \mathrm{O}_{2} \mathrm{l}^{-1}$ (Table 1). We chose to study ca. 2 mo old $M$. affinis, since a pilot study had shown that mortality was very high just after release from the marsupium. A total of $15 \mathrm{M}$. balthica, ranging from small to large individuals ( 0.4 to $26.8 \mathrm{mg}$ shell-free dry mass), were added to each of 6 aquaria in the $M$. balthica treatment. In a second treatment, $5 H$. spinulosus with a dry mass ranging from 16 to $31 \mathrm{mg}$ were added to each of 6 aquaria. Each replicate of a treatment received a similar distribution of size classes of $M$. balthica and $H$. spinulosus, in order to add a similar total biomass to each aquarium. In a third treatment, 100 juvenile $M$. affinis (not weighed since water evaporation affects
Table 1. Experimental treatments and their abbreviations

\begin{tabular}{|lcc|}
\hline Experiment & $\begin{array}{c}\mathrm{O}_{2} \text { concentration } \\
\left(\mathrm{mg} \mathrm{l}^{-1}\right)\end{array}$ & Abbreviation \\
\hline Moderate hypoxia & Control 10.0 & $\mathrm{C} 10$ \\
& Moderate hypoxia 6.0 & MH6 \\
& Moderate hypoxia 3.0 & MH3 \\
Severe hypoxia & Control 10.6 & C10.6 \\
Expt 1 & Severe hypoxia 0.8 & SH0.8 \\
Severe hypoxia & Control 8.9 & C8.9 \\
Expt 2 & Severe hypoxia 1.6 & SH1.6 \\
\hline
\end{tabular}

the wet weight, and it is difficult to determine a correct dry weight on the very small juvenile amphipods) were added to each of 10 aquaria by randomly adding 10 batches, each containing 10 juvenile $M$. affinis, to each aquarium (Table 2). Radioactivity uptake is given on an individual basis for juvenile amphipods and for dry mass of subadult amphipods and the other species (Table 2, see Figs. 1, 3 \& 4).

Sieved sediment ( $2 \mathrm{~cm}$ thick layer) was added to 21 aquaria (Erlenmeyer flasks with a bottom area of $227 \mathrm{~cm}^{2}$ ) and the aquaria covered with green plastic film according to Sundelin (1983) to simulate light conditions resembling those at 30 to $40 \mathrm{~m}$ depth. Aquaria in all treatments were supplied with filtered $(280 \mu \mathrm{m}$ filter), flow-through, natural brackish water (mean flow \pm SE: $1.00 \pm 0.021 \mathrm{~h}^{-1}$, salinity: 7) from $37 \mathrm{~m}$ depth, where the studied species are common. Water with different oxygen concentration $\left(5^{\circ} \mathrm{C}, \mathrm{MH}\right.$ experiment) was obtained by bubbling water with nitrogen gas in 5001 barrels. When the water level in a barrel was low, we switched to a 'new' barrel containing water with the same oxygen concentration as the one replaced. The empty barrels were refilled daily, and oxygen concentrations were adjusted to experimental levels by bubbling with nitrogen gas. Oxygen levels were maintained during the experiment by automatic bubbling of nitrogen gas. Controls received water $\left(5^{\circ} \mathrm{C}\right)$ pumped up continuously from $37 \mathrm{~m}$ depth. Peristaltic multi-channel pumps (Alitea) distributed water to the aquaria. Oxygen concentrations were measured with OXI meters (WTW, Wissenschaftlich-Technische Werkstätten), with an OXI 323-B electrode, calibrated by Winkler analyses. First animals and, then, a suspension of $2 \mathrm{ml}{ }^{14} \mathrm{C}$-labelled algae (Batch aa) were added to all aquaria. After the algae had settled for $30 \mathrm{~min}$, the water flow was turned on.

Oxygen content was measured in all aquaria with Macoma balthica and Halicryptus spinulosus both during and at the end of the experiment. To prevent escape of swimming amphipods, oxygen measures were only made at the end of the experiment in the amphipod treatments (Table 2). 
Table 2. Moderate hypoxia (MH) and severe hypoxia ( $\mathrm{SH}$ ) experiments (C: controls). The numbers after $\mathrm{MH}, \mathrm{SH}$ and $\mathrm{C}$ denote the lowest oxygen value measured within each treatment in the $\mathrm{MH}$ and $\mathrm{SH}$ experiments. Oxygen range in the SH experiments: Expt 1: 0.8 to 2.0 (mean $1.3 \pm 0.1$ ) and 10.6 to 10.9 (mean $10.8 \pm 0.0$ ); Expt 2: 1.6 to 2.0 (mean 1.8 \pm 0.0 ) and 8.9 to 9.6 (mean $9.1 \pm 0.1$ ). Mean values $( \pm \mathrm{SE})$ are given

\begin{tabular}{|c|c|c|c|c|c|c|c|c|c|c|c|}
\hline \multirow[t]{2}{*}{ Expt. } & \multirow{2}{*}{\multicolumn{3}{|c|}{$\begin{array}{l}\text { Replicates } \\
\text { (no) }\end{array}$}} & \multirow{2}{*}{$\begin{array}{l}\text { Start } \\
\text { (n) }\end{array}$} & \multirow{2}{*}{\multicolumn{2}{|c|}{$\underset{(\text { mean } \pm \mathrm{SE})}{-}$}} & \multirow{2}{*}{$\begin{array}{l}\text { Density } \\
\text { (ind. } \mathrm{m}^{-2} \text { ) }\end{array}$} & \multirow{2}{*}{$\begin{array}{l}\text { Dry mass } \\
\text { Final (mg) }\end{array}$} & \multirow{2}{*}{$\begin{array}{l}\text { Radioactive } \\
\text { uptake } e^{\mathrm{a}, \mathrm{b}}\end{array}$} & \multicolumn{2}{|c|}{$\left[\mathrm{O}_{2}\right]\left(\mathrm{mg} \mathrm{l}^{-1}\right)$} \\
\hline & & & & & & & & & & During & Final \\
\hline \multicolumn{12}{|c|}{ Moderate hypoxia } \\
\hline \multicolumn{12}{|c|}{ Monoporeia affinis (juvenile) } \\
\hline & MH3 & & 10 & $100 \pm 1$ & $38 \pm 9$ & $38 \pm 9$ & 4500 & - & $700 \pm 50^{\mathrm{a}}$ & - & $3.3 \pm 0.1$ \\
\hline & MH6 & & 10 & $100 \pm 1$ & $67 \pm 9$ & $67 \pm 9$ & 4500 & - & $500 \pm 100^{\mathrm{a}}$ & - & $6.0 \pm 0.1$ \\
\hline & $\mathrm{C} 10$ & & 10 & $100 \pm 1$ & $49 \pm 11$ & $49 \pm 11$ & 4500 & - & $500 \pm 25^{\mathrm{a}}$ & - & $10.1 \pm 0.1$ \\
\hline \multicolumn{12}{|c|}{ Macoma balthica } \\
\hline & МH3 & & 6 & $15 \pm 1$ & $15 \pm 1$ & 100 & 700 & - & $3100 \pm 500^{b}$ & $3.2 \pm 0.1$ & $3.3 \pm 0.1$ \\
\hline & MH6 & & 6 & $15 \pm 1$ & $15 \pm 1$ & 100 & 700 & - & $3600 \pm 700^{b}$ & $5.9 \pm 0.1$ & $5.9 \pm 0.1$ \\
\hline & $\mathrm{C} 10$ & & 6 & $15 \pm 1$ & $15 \pm 1$ & 100 & 700 & - & $4400 \pm 400^{\mathrm{b}}$ & $9.0 \pm 0.1$ & $9.8 \pm 0.1$ \\
\hline \multicolumn{12}{|c|}{ Halicryptus spinulosus } \\
\hline & MH3 & & 6 & 5 & 5 & 100 & 200 & - & $19 \pm 7^{b}$ & $3.2 \pm 0.1$ & $3.3 \pm 0.1$ \\
\hline & MH6 & & 6 & 5 & 5 & 100 & 200 & - & $15 \pm 3^{b}$ & $5.9 \pm 0.1$ & $5.9 \pm 0.1$ \\
\hline & $\mathrm{C} 10$ & & 6 & 5 & $5 \pm 1$ & $97 \pm 3$ & 200 & - & $22 \pm 3^{b}$ & $9.0 \pm 0.1$ & $9.8 \pm 0.1$ \\
\hline \multicolumn{12}{|c|}{ Severe hypoxia } \\
\hline \multicolumn{12}{|c|}{ M. affinis } \\
\hline \multirow[t]{2}{*}{ Expt 1} & SH0.8 & & 10 & 4 & $0.6 \pm 0.2$ & $15 \pm 6$ & 910 & $1.18 \pm 0.11$ & $3600 \pm 900^{\mathrm{b}}$ & - & $1.3 \pm 0.1$ \\
\hline & C10.6 & & 10 & 4 & $3.4 \pm 0.2$ & $85 \pm 6$ & 910 & $0.98 \pm 0.08$ & $21300 \pm 3400^{b}$ & - & $10.8 \pm 0.1$ \\
\hline \multirow[t]{2}{*}{ Expt 2} & SH1.6 & & 10 & 4 & $2.6 \pm 0.2$ & $65 \pm 6$ & 910 & $2.69 \pm 0.25$ & $400 \pm 100^{\mathrm{b}}$ & - & $1.8 \pm 0.1$ \\
\hline & C8.9 & & 10 & 4 & $3.7 \pm 0.2$ & $92 \pm 4$ & 910 & $2.23 \pm 0.26$ & $2800 \pm 800^{\mathrm{b}}$ & - & $9.1 \pm 0.1$ \\
\hline \multicolumn{12}{|c|}{ Pontoporeia femorata } \\
\hline \multirow[t]{2}{*}{ Expt 1} & SH0.8 & & 10 & 4 & 0 & 0 & 910 & - & - & - & $1.3 \pm 0.1$ \\
\hline & C10.6 & & 10 & 4 & $3 \pm 0.3$ & $75 \pm 7$ & 910 & $2.46 \pm 0.19$ & $2900 \pm 1000^{b}$ & - & $10.8 \pm 0.1$ \\
\hline \multirow[t]{2}{*}{ Expt 2} & SH1.6 & & 10 & 4 & $2.3 \pm 0.4$ & $58 \pm 10$ & 910 & $2.82 \pm 0.43$ & $400 \pm 200^{\mathrm{b}}$ & - & $1.8 \pm 0.1$ \\
\hline & C8.9 & & 10 & 4 & $3.5 \pm 0.2$ & $88 \pm 4$ & 910 & $1.61 \pm 0.07$ & $600 \pm 100^{\mathrm{b}}$ & - & $9.1 \pm 0.1$ \\
\hline \multicolumn{12}{|c|}{ M. affinis $+P$. femorata } \\
\hline \multirow[t]{4}{*}{ Expt 1} & SH0.8 & M. aff. & 5 & 4 & 0 & 0 & 1818 & - & - & - & $1.3 \pm 0.1$ \\
\hline & & P. fem. & 5 & 4 & 0 & 0 & 1818 & - & - & - & $1.3 \pm 0.1$ \\
\hline & C10.6 & M. aff. & 5 & 4 & $3.4 \pm 0.6$ & $85 \pm 15$ & 1818 & $1.03 \pm 0.13$ & $23090 \pm 4810^{\mathrm{b}}$ & - & $10.8 \pm 0.1$ \\
\hline & & P. fem. & 5 & 4 & $3.2 \pm 0.4$ & $80 \pm 9$ & 1818 & $2.38 \pm 0.31$ & $2500 \pm 800^{\mathrm{b}}$ & - & $10.8 \pm 0.1$ \\
\hline Expt 2 & SH1.6 & M. aff. & 5 & 4 & $3.2 \pm 0.4$ & $80 \pm 9$ & 1818 & $2.93 \pm 0.15$ & $380 \pm 130^{\mathrm{b}}$ & - & $1.8 \pm 0.1$ \\
\hline & & $P$. fem. & 5 & 4 & $2.4 \pm 0.6$ & $60 \pm 15$ & 1818 & $1.52 \pm 0.10$ & $400 \pm 100^{b}$ & - & $1.8 \pm 0.1$ \\
\hline & C8.9 & M. aff. & 5 & 4 & $3.4 \pm 0.4$ & $85 \pm 10$ & 1818 & $2.19 \pm 0.47$ & $1750 \pm 670^{\mathrm{b}}$ & - & $9.1 \pm 0.1$ \\
\hline & & P. fem. & 5 & 4 & $3.4 \pm 0.2$ & $85 \pm 6$ & 1818 & $1.57 \pm 0.08$ & $1000 \pm 200^{\mathrm{b}}$ & - & $9.1 \pm 0.1$ \\
\hline M. balth & & & & & & & & & & & \\
\hline Expt 1 & SH0.8 & & 10 & 4 & $4 \pm 0$ & $100 \pm 0$ & 910 & $28.4 \pm 1.6$ & $1400 \pm 200^{\mathrm{b}}$ & - & $1.3 \pm 0.1$ \\
\hline & C10.6 & & 10 & 4 & $3.9 \pm 0.1$ & $98 \pm 2$ & 910 & $31.4 \pm 1.7$ & $3000 \pm 290^{\mathrm{b}}$ & - & $10.8 \pm 0.1$ \\
\hline Expt 2 & SH1.6 & & 10 & 4 & $3.9 \pm 0.1$ & $98 \pm 2$ & 910 & $27.4 \pm 1.6$ & $1100 \pm 200^{\mathrm{b}}$ & - & $1.8 \pm 0.1$ \\
\hline & C8.9 & & 10 & 4 & $3.9 \pm 0.1$ & $98 \pm 2$ & 910 & $35.6 \pm 2.6$ & $700 \pm 100^{\mathrm{b}}$ & - & $9.1 \pm 0.1$ \\
\hline H. spinu & sus & & & & & & & & & & \\
\hline Expt 1 & SH0.8 & & 5 & 3 & $2.6 \pm 0.4$ & $87 \pm 13$ & 682 & $8.9 \pm 2.3$ & $70 \pm 20^{\mathrm{b}}$ & - & $1.3 \pm 0.1$ \\
\hline & C10.6 & & 5 & 3 & $2.8 \pm 0.2$ & $93 \pm 7$ & 682 & $7.6 \pm 1.7$ & $110 \pm 10^{\mathrm{b}}$ & - & $10.8 \pm 0.1$ \\
\hline Expt 2 & SH1.6 & & 5 & 3 & $3 \pm 0$ & $100 \pm 0$ & 682 & $7.5 \pm 1.1$ & $130 \pm 30^{\mathrm{b}}$ & - & $1.8 \pm 0.1$ \\
\hline & C8.9 & & 5 & 3 & $3 \pm 0$ & $100 \pm 0$ & 682 & $5.9 \pm 1.2$ & $200 \pm 40^{\mathrm{b}}$ & - & $9.1 \pm 0.1$ \\
\hline
\end{tabular}

Severe hypoxia: The aim was to study the effect of different oxygen concentrations on the feeding of Macoma balthica, Halicryptus spinulosus, subadult Monoporeia affinis and subadult Pontoporeia femorata. The effect of $\mathrm{SH}$ on the uptake of radioactivity was studied in single-species treatments with $M$. balthica (size range 21 to $47.6 \mathrm{mg}$ shell-free dry mass), $H$. spinulosus (3.1 to $17.2 \mathrm{mg})$, subadult $M$. affinis (0.7 to $3.4 \mathrm{mg}$ ) and subadult $P$. femorata (1.2 to $4.4 \mathrm{mg}$ ) alone, and in mixed treatments with the subadult amphipods together (Table 2). The aim of the mixed treatment was to study whether the radioactivity uptake in $\mathrm{SH}$ was different when subadult amphipod species were exposed separately or species were mixed (referred to as single and mixed in the text). $P$. femorata lives deeper in the sediment than $M$. affinis, and when the 2 co-occur, the burrowing depth of $P$. femorata increases (Hill \& Elmgren 1987). Treatments with H. spinulosus and mixed amphipods were replicated 5 times, the other treatments, 10 times. Two experiments were conducted sucsessively in containers provided with recirculating artificial water at $5^{\circ} \mathrm{C}$ in a temperature- 
controlled room. The ambient light regime $(16 \mathrm{~h}$ light: $8 \mathrm{~h}$ dark) was regulated by a timer connected to a dim green light. The control treatment had near-natural oxygen conditions and lower oxygen concentrations were obtained by bubbling the water with nitrogen gas (Table 1). To maintain stable oxygen concentrations the flow of nitrogen gas was automatically regulated by magnetic valves controlled by oxygen meters (AOWL2/KOB/421, Processtyrning AB), calibrated and adjusted to oxygen concentrations determined by Winkler analyses.

Round plastic beakers (bottom area $44 \mathrm{~cm}^{2}$ ), with walls partly made of $0.2 \mathrm{~mm}$ phytoplankton net that allowed water flow through the aquaria, were filled with sieved sediment to a depth of $2 \mathrm{~cm}$. These aquaria were placed in rectangular $(2.5 \times 0.4 \times 0.2 \mathrm{~m})$ containers filled with re-circulating (EHEIM pump $440 \mathrm{l} \mathrm{h}^{-1}$ ) artificial seawater (salinity 6.5), 1 container per treatment. After addition of the test animals and $1 \mathrm{ml}$ radioactive algal suspension, spread on top of the sediment, the aquaria were closed with plastic lids. The algae were added to the SH Expt 1 (Batch a1) soon after harvesting, and then stored in a cooler for a week, during which some of the ${ }^{14} \mathrm{C}$-activity was lost (Batch a2), before use in the SH Expt 2.

Statistical analyses. In the $\mathrm{MH}$ experiment the radioactivity uptake was analysed with a 1-factor ANOVA for juvenile Monoporeia affinis, and Tukey's test for unequal n, and for Halicryptus spinulosus and Macoma balthica a 2-factor ANOVA was used with species and oxygen concentration as fixed factors [log $(x+1)$-transformed data]. A 1-factor ANOVA analysed the survival of juvenile $M$. affinis. The dry mass of $M$. balthica and $H$. spinulosus was compared with a 2-factor ANOVA (fixed factors: species and oxygen concentration, log-transformed data), followed by Tukey's test for unequal $n$.

The radioactivity uptake in the $\mathrm{SH}$ experiments was compared using 2 -factor ANOVA with species and oxygen concentration as fixed factors $(\log [x+1]$-transformed data). Significant results were tested by Tukey's test for unequal n. Survival data were analysed with a 2-factor ANOVA (fixed factors: species and oxygen concentration), followed by Tukey's test for unequal $n$.

\section{RESULTS}

\section{Moderate hypoxia}

The uptake of radioactivity by juvenile Monoporeia affinis was significantly highest at the lowest oxygen concentration tested (Fig. 1a, Table 2$)\left(F_{2,25}=4.94, \mathrm{p}=\right.$ $0.016 ;{ }^{\Psi} \mathrm{p}<0.05-{ }^{\Psi}$ denotes Tukey's test for unequal $\mathrm{n}$ ). The survival of juvenile $M$. affinis ranged from 38 to
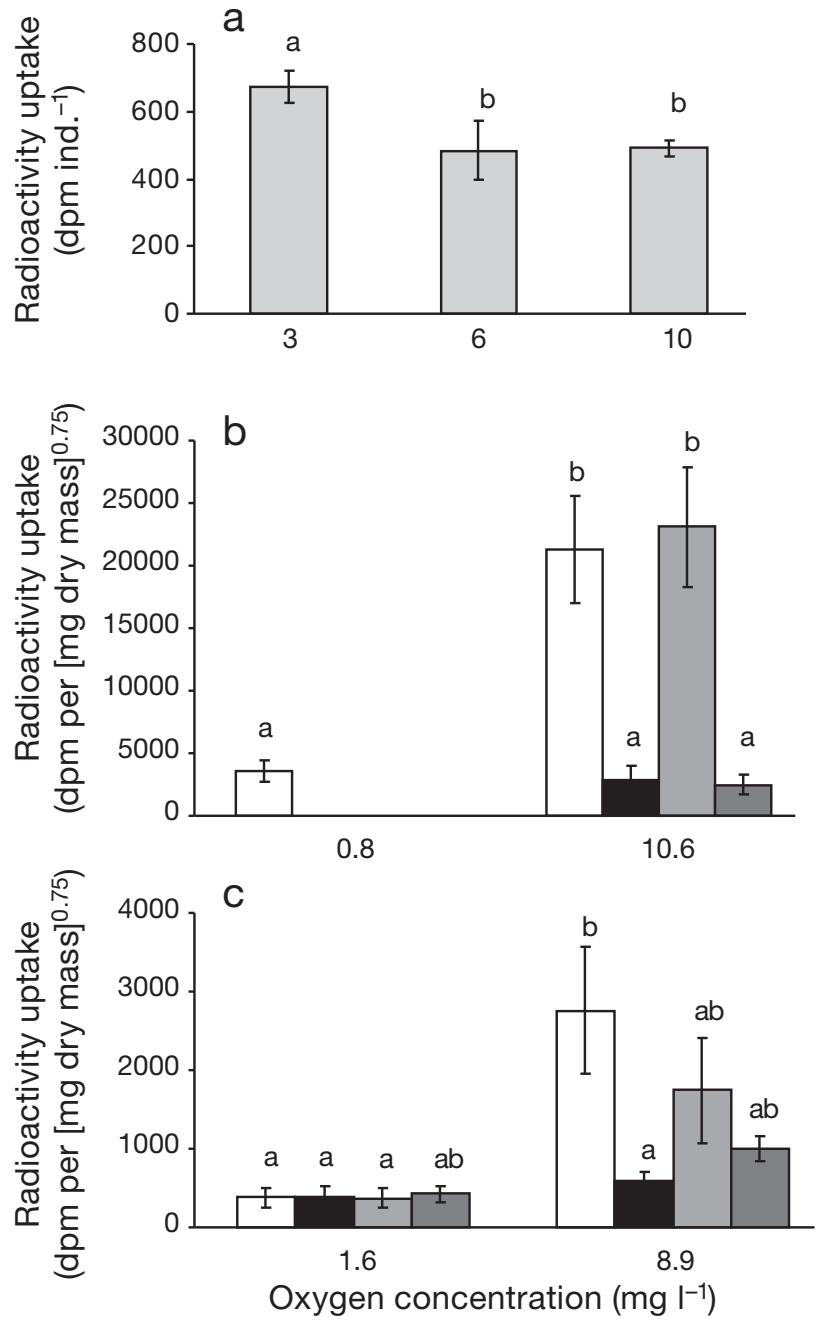

Fig. 1. (a) Moderate hypoxia $(\mathrm{MH})$ experiment: radioactivity uptake (dpm ind.$^{-1}$ ) after $7 \mathrm{~d}$ by juvenile Monoporeia affinis in 3 different oxygen concentrations. $(b, c)$ Severe hypoxia $(\mathrm{SH})$ Expts 1 and 2: radioactivity uptake (dpm per [mg dry mass $]^{0.75}$ ) by subadult amphipods in low and high oxygen concentrations after $7 \mathrm{~d}$. Mean values $( \pm$ SE) are given. For $(\mathrm{b}, \mathrm{c}) \square$ : single Monoporeia affinis; $\square$ : single Pontoporeia femorata; $\square$ : mixed M. affinis; $\square$ : mixed P. femorata. Different letter codes denote significant differences. Due to different activity levels of the algal food added to the different experiments, responses cannot be compared between experiments

$67 \%$, with no significant difference among treatments MH3, MH6 and C10 $\left(F_{2,26}=2.62, \mathrm{p}=0.09\right.$; Fig. 2, Tables $1 \& 2$ ).

The radioactivity uptake by Macoma balthica was not significantly different among oxygen levels (MH3, MH6 and C10) $\left(F_{2,30}=1.92, p=0.16\right.$; Fig. 3a). All $M$. balthica survived in all treatments. No differences in average dry mass of $M$. balthica were detected $\left(F_{2,30}=0.31, \mathrm{p}=0.74\right)$.

The average radioactivity uptake of Halicryptus spinulosus was low throughout the experiment and not significantly different among the tested oxygen levels 


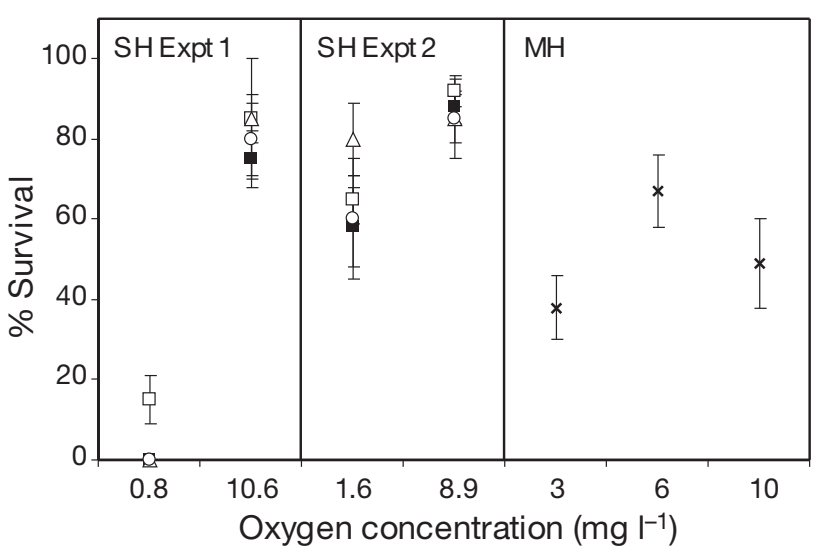

Fig. 2. Survival of subadult Monoporeia affinis and Pontoporeia femorata in $\mathrm{SH}$ experiments (SH Expt 1 and $\mathrm{SH}$ Expt 2) and of juvenile $M$. affinis in the $\mathrm{MH}$ experiment. Mean values $( \pm \mathrm{SE})$ are given. $\square$ : single $M$. affinis; $\mathbf{~}$ : single $P$. femorata; $\Delta:$ M. affinis mix; O: P. femorata mix; $\mathrm{x}$ : juvenile M. affinis

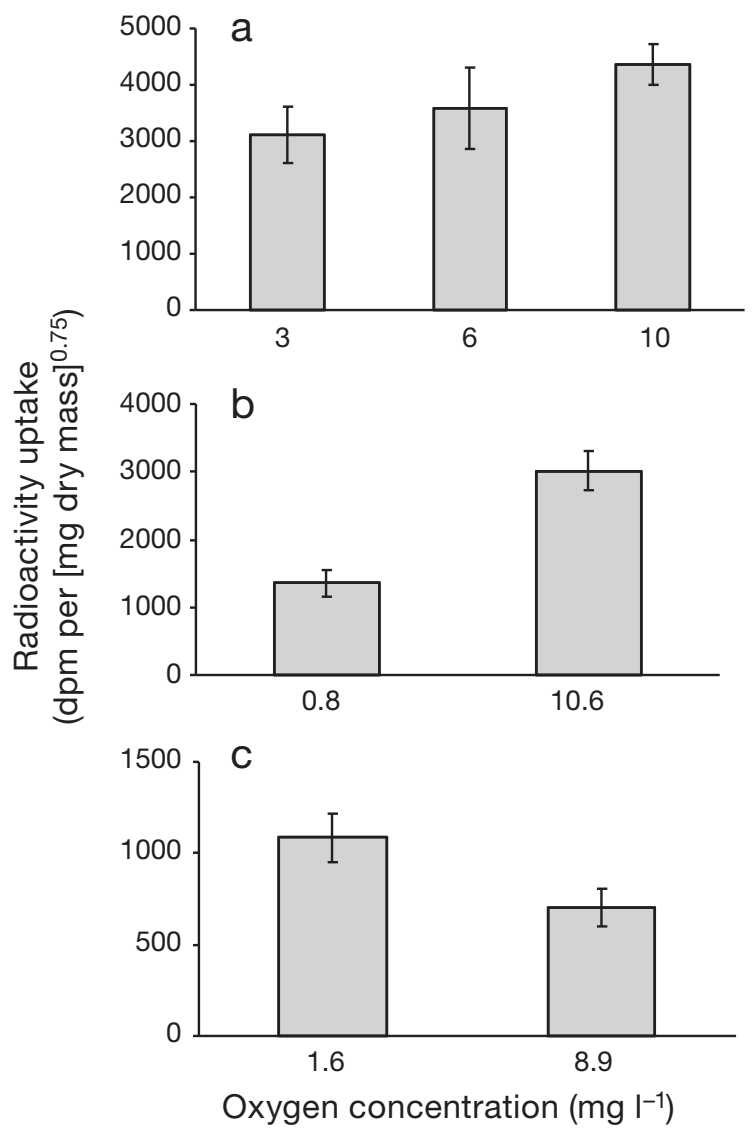

Fig. 3. Radioactivity uptake (dpm per [mg dry mass $]^{0.75}$ ) after $7 \mathrm{~d}$ by Macoma balthica in various oxygen concentrations: (a) $\mathrm{MH}$ experiment and (b,c) SH Expts 1 and 2. Mean values $( \pm \mathrm{SE})$ are given. Due to different activity levels of the algal food added to the different experiments, responses cannot be compared between experiments
$\left(F_{2,30}=1.92, \mathrm{p}=0.16\right.$; Table 2, Fig. 4a). Survival of $H$. spinulosus was high $(\geq 97 \%)$ in all treatments. No significant differences were found in average dry mass $\left(F_{2,30}=0.31, \mathrm{p}=0.74\right)$.

\section{Severe hypoxia}

The uptake of radioactivity was significantly different between oxygen concentrations, and the interaction effect for species and oxygen concentration was also significant (Table 3). In the SH0.8 treatment Monoporeia affinis took up only about $17 \%$ of the radioactivity taken up in the corresponding single and mixed C10.6 treatments $\left({ }^{\Psi} \mathrm{p}<0.05\right.$; Table 2$)$. In the C10.6 treatment, radioactivity uptake was significantly lower for Pontoporeia femorata than for $M$. affinis, both in the single and mixed treatments $\left({ }^{\Psi} \mathrm{p}<0.05\right.$; Fig. $\left.1 \mathrm{~b}\right)$. No difference in radioactivity uptake was found in the C10.6 treatments between $M$. affinis only or when

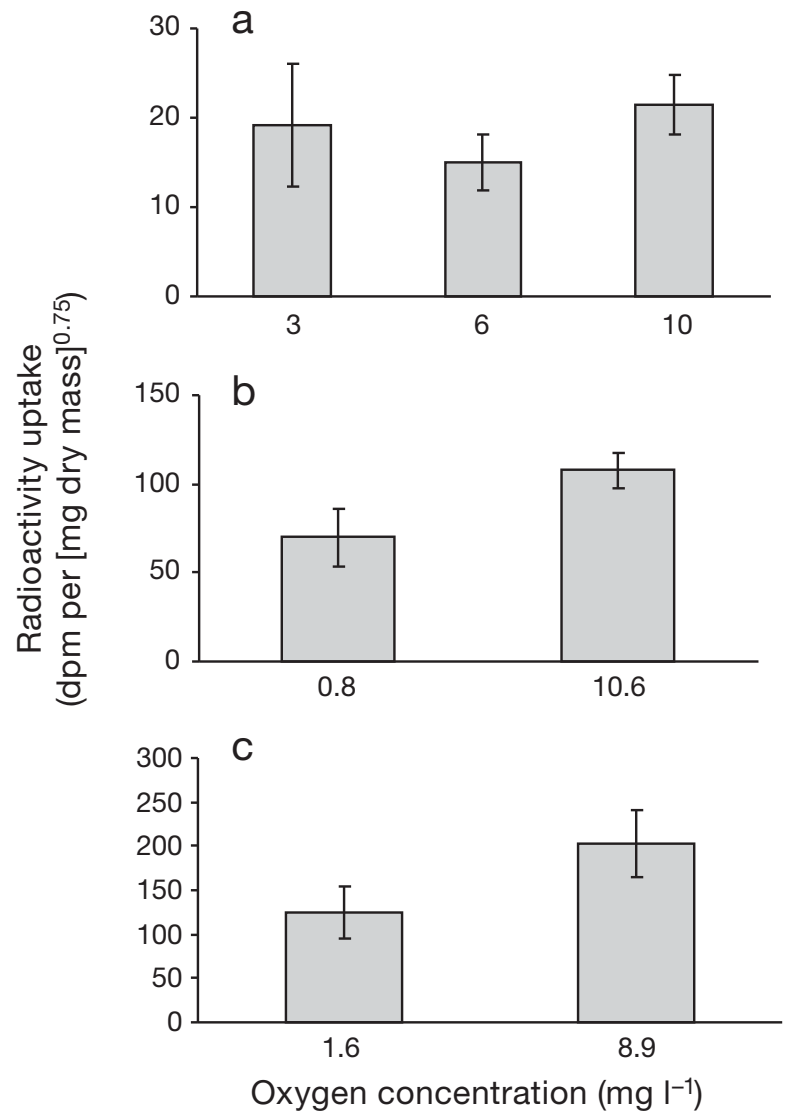

Fig. 4. Radioactivity uptake (dpm per [mg dry mass $]^{0.75}$ ) by Halicryptus spinulosus in various oxygen concentrations, after $7 \mathrm{~d}$ : (a) MH experiment and (b,c) SH Expts 1 and 2. Mean values $( \pm$ SE) are given. Due to different activity levels of the algal food added to the different experiments, responses cannot be compared between experiments 
Table 3. Two-factor ANOVA of radioactivity uptake of species in different oxygen concentrations. Factors are species (Monoporeia affinis, Pontoporeia femorata, M. affinis + P. femorata, Macoma balthica and Halicryptus spinulosus) and oxygen concentration (C10.6, C8.9, SH1.6 and SH0.8, where the numbers represent $\mathrm{mg} \mathrm{O}_{2} \mathrm{I}^{-1}$ ). ${ }^{* * *} \mathrm{p}<0.001$

\begin{tabular}{|lrrr|}
\hline Source of variation & df & MS & \multicolumn{1}{c|}{$F$} \\
\hline Species & 5 & 9.25 & $87.08^{* * *}$ \\
$\mathrm{O}_{2}$ concentration & 3 & 25.48 & $239.78^{* * *}$ \\
Species $\times \mathrm{O}_{2}$ conc. & 15 & 4.70 & $44.16^{* * *}$ \\
\hline
\end{tabular}

mixed together with $P$. femorata, nor between $P$. femorata when single or mixed $\left({ }^{\Psi} p>0.05\right)$. Survival of the amphipods was significantly affected by the oxygen concentration. The interaction effect for species and oxygen concentration was significant (Table 4). The only amphipods surviving in the SH0.8 treatment of SH Expt 1 were $M$. affinis, but survival was significantly lower than for $M$. affinis (single and mixed) in the C10.6 treatment $\left({ }^{\Psi} \mathrm{p}>0.05\right.$; Fig. 2, Table 2). Survival was not significantly different between single and mixed $M$. affinis or between single and mixed $P$. femorata in the C10.6 treatment $\left({ }^{\Psi} \mathrm{p}<0.05\right.$; Table 2).

In $\mathrm{SH}$ Expt 2, radioactivity uptake was significantly different between oxygen concentrations, the interaction effect for species and oxygen concentration was significant (Table 3). Single and mixed Monoporeia affinis and single Pontoporeia femorata in the SH1.6 and single $P$. femorata in the C8.9 treatment had a significantly lower radioactivity uptake than single $M$. affinis in the C8.9 treatment $\left({ }^{\Psi} \mathrm{p}<0.05\right.$; Fig. $\left.1 \mathrm{c}\right)$. In the C8.9 treatment, radioactivity uptake was significantly lower for single $P$. femorata than for single $M$. affinis $\left({ }^{\Psi} \mathrm{p}<0.05 ;\right.$ Fig. 1c). No difference in radioactivity uptake was found within either of the C8.6 or SH1.6 treatments between $M$. affinis when single or mixed, nor between $P$. femorata when single or mixed $\left({ }^{\Psi} \mathrm{p}>0.05\right)$. Survival differed significantly between oxygen levels. The interaction effect for species and oxygen concentration was significant (Table 4). Sur-

Table 4. Two-factor ANOVA of survival of species in different oxygen concentrations. Factors are species (Monoporeia affinis, Pontoporeia femorata, M. affinis + P. femorata, Macoma balthica and Halicryptus spinulosus) and oxygen concentration (C10.6, C8.9, SH1.6 and SH0.8, where the numbers represent $\mathrm{mg} \mathrm{O}_{2} \mathrm{l}^{-1}$ ). ${ }^{* * *} \mathrm{p}<0.001$

\begin{tabular}{|lrrr|}
\hline Source of variation & df & MS & $F$ \\
\hline Species & 5 & 14.97 & $32.90^{* * *}$ \\
$\mathrm{O}_{2}$ concentration & 3 & 43.24 & $95.00^{* * *}$ \\
Species $\times \mathrm{O}_{2}$ conc. & 15 & 4.70 & $10.33^{* * *}$ \\
\hline
\end{tabular}

vival of single $M$. affinis and single $P$. femorata in the SH1.6 treatment was significantly lower than for single $M$. affinis and single $P$. femorata, respectively, in the C8.9 treatment $\left({ }^{\Psi} \mathrm{p}<0.05\right.$; Fig. 2, Tables $\left.2 \& 4\right)$, whereas no difference was found when a similar comparison was made for the corresponding mixed treatments ( ${ }^{\Psi} \mathrm{p}>0.05 ;$ Table 2). No significant difference was found between single and mixed $M$. affinis or between single and mixed $P$. femorata in neither the C8.9, nor in the SH1.6 treatments ( ${ }^{\Psi} \mathrm{p}<0.05$; Table 2). Survival did not differ significantly within oxygen level (C10.6, C8.9, SH1.6) among single $M$. affinis, single $P$. femorata and the mixed amphipod species.

No significant effect on the radioactivity uptake in Macoma balthica in oxygen concentrations tested was detected in either of the $2 \mathrm{SH}$ experiments $\left({ }^{\Psi} \mathrm{p}>0.05\right.$; Fig. 3b,c). Survival of $M$. balthica was high (>98\%) in all treatments (both experiments), and the average shell-free dry mass of survivors was not significantly different between treatments in $\mathrm{SH}$ Expt 1 and 2 $\left(F_{3,52}=0.85, \mathrm{p}=0.47\right.$; Table 2$)$.

The uptake of radioactivity by Halicryptus spinulosus was always low, and not significantly different between control and low oxygen conditions ( ${ }^{\Psi} \mathrm{p}>0.05$; Fig. 4b,c). All H. spinulosus in SH Expt 2 survived, and mortality was a low $(<13 \%)$ in both treatments in $\mathrm{SH}$ Expt $1\left({ }^{\Psi} \mathrm{p}>0.05\right)$. The average final dry mass of $H$. spinulosus did not vary significantly between treatments in SH Expts 1 and $2\left(F_{3,52}=0.85, \mathrm{p}=0.47\right.$; Table 2). (Note the radioactivity in test animals from the different experiments is not comparable since different algal batches were used.)

\section{DISCUSSION}

Animals from different taxonomic groups tend to differ in tolerance to hypoxia and anoxia. Generally, crustaceans are more sensitive to anoxic and hypoxic conditions than are priapulids and bivalves (Diaz \& Rosenberg 1995, Karlson et al. 2002). Tolerance to poor oxygen conditions varies between species within groups (Gray et al. 2002 and references therein) and also between life stages within species, the younger stages generally being more sensitive to low oxygen concentrations (Wang \& Widdows 1991).

\section{Feeding}

The radioactivity uptake by juvenile Monoporeia affinis was significantly higher in the MH3 treatment than in the other treatments. The low oxygen concentration may have forced the juveniles to concentrate their feeding more to the uppermost sediment layer, 
where the labelled algae were found. Specimens that died during the experiment may have been eaten by conspecifics (Hill 1992), which would increase their radioactivity, depending on how much radioactivity the dead specimens had accumulated and on how large a portion of the dead conspecifics was ingested. Swimming activity in $M$. affinis and Pontoporeia femorata decreases as oxygen concentration decreases, but at low oxygen levels (1.0 and $1.7 \mathrm{mg} \mathrm{O}_{2} \mathrm{l}^{-1}$, respectively) they are forced towards the sediment surface and increase swimming (Johansson 1997a). Physiologically, aquatic invertebrates show an adaptive response to $\mathrm{MH}$ by increased ventilatory frequency accompanied by a decrease in the number of ventilatory pauses (Taylor 1982). They regulate oxygen transport by increased cardiac output and blood pigment (hemoglobin/hemocyanin) synthesis and expression (Terwilliger 1998, Rabalais et al. 2002). It is probable that induced hyperventilation during hypoxia (McMahon 2002) affects juveniles more seriously, since they have a higher metabolic rate than larger individuals and, therefore, are less tolerant to the resulting stress (Lockwood 1968). The higher concentrations of $3 \mathrm{mg}$ $\mathrm{O}_{2} \mathrm{l}^{-1}$ in the $\mathrm{MH}$ experiment may have increased pleopod beating, resulting in a higher metabolic rate that the juveniles compensated for by increased feeding. In contrast to $\mathrm{SH}$, which decreases metabolism, $\mathrm{MH}$ (>2 to $3 \mathrm{mg} \mathrm{O}_{2} \mathrm{l}^{-1}$ ) has been reported to result in slightly increased metabolism in the copepod Calanus exinus (Svetlichny et al. 2000). Hypoxia-tolerant species differ from hypoxia-sensitive species, and, contrary to sensitive species, metabolism, locomotory activity and ventilation rates show a drastic decrease, which partly explains their resistance to hypoxia (Normant et al. 1998).

Oxygen concentrations of 0.8 and $1.6 \mathrm{mg} \mathrm{l}^{-1}$ drastically decreased the feeding rate of subadult single Pontoporeia femorata and Monoporeia affinis, and of mixed $M$. affinis, whereas such a decrease was indicated, but not statistically significant, for mixed $P$. femorata. Further, single $P$. femorata had a significantly lower radioactivity uptake than $M$. affinis in the C8.9 treatment. Most crustaceans can shift to anaerobic metabolism during hypoxia, resulting in a decrease in adenosine triphosphate (ATP) and phosphagen, utilisation of glycogen and glutamate, and accumulation of lactate and alanine (Zebe 1991, Hervant et al. 1996). The decreased glycogen and phosphagen stores are accompanied by reduced energetic expenditures for locomotory activity and ventilation, extending the survival under anaerobiosis, but also reducing feeding activity (Hervant et al. 1997).

Although Pontoporeia femorata lives deeper in the sediment than Monoporeia affinis, both amphipods have been reported to feed mainly on surface sediment
(Lopez \& Elmgren 1989). Therefore, the labelled algae were added on the sediment surface. However, when subadult amphipods were offered radioactively labelled diatoms added on the sediment surface (Byrén et al. 2002) and stable isotope labelled diatoms mixed into the sediment (Byrén et al. 2006), it turned out that the 2 amphipods have different feeding niches. $M$. affinis fed mainly on surface sediment, while $P$. femorata was mainly a subsurface feeder. Further, ${ }^{14} \mathrm{C}$-labelled algae mixed into the sediment were assimilated in similar amounts by the 2 amphipod species at good oxygen concentrations (Byrén et al. 2002). Similarly, single $M$. affinis had a higher radioactive uptake at C10.6 and C8.9 than did single $P$. femorata. Bioturbation (Cederwall 1979, Ejdung 1998) causes mixing of sediment particles in the upper $5 \mathrm{~cm}$ of the sediment (Lopez \& Elmgren 1989), but is unlikely to have greatly mixed the sediment during our short-term experiments. The much lower uptake by $P$. femorata than by $M$. affinis in our experiments probably mainly represents evidence of surface feeding by subadult $M$. affinis as reported by Byrén et al. (2002, 2006).

The labelled algae were added on top of the sediment surface in all our experiments, mimicking the in situ situation, where most of the organic material settles on the sediment surface in a few pulses a year. Decomposition of the settled material requires oxygen, but as long the oxygen concentrations remain preventing activity levels, parts of this material may be mixed down into the sediment by bioturbation, enriching deeper sediment layers. Monoporeia affinis and Pontoporeia femorata took up equal amounts of radioactivity when the organic material was mixed into the sediment (Byrén et al. 2002). Furthermore, under normoxic oxygen conditions $M$. affinis has higher metabolic and feeding rates than $P$. femorata (Cederwall 1979, Lopez \& Elmgren 1989). When oxygen content was low (SH1.6), the feeding rate of $M$. affinis was as low as that of $P$. femorata. This could possibly be connected to decreased swimming activity and a shorter swimming period (Johansson 1997a).

No significant reduction of radioactivity uptake by Macoma balthica was found after $7 \mathrm{~d}$ of exposure to low oxygen concentrations. When oxygen is sparse or absent, $M$. balthica becomes inactive, and, the longer the exposure to anoxia, the lower the metabolic rate (Dries \& Theede 1976). The behaviour of $M$. balthica also changes as oxygen concentrations decrease, e.g. the rate of burrowing decreases at oxygen concentrations $<1 \mathrm{mg} \mathrm{O}_{2} \mathrm{l}^{-1}$ (Tallqvist 2001).

In our $7 \mathrm{~d}$ experiments, all Halicryptus spinulosus remained buried in the sediment, and were not forced to the sediment surface even at the lowest oxygen conditions, although they have been found on the sediment surface when exposed to anoxia (Oeschger \& 
Storey 1990). The very low uptake of radioactivity from labelled algae deposited on the sediment surface and the absence of an effect on uptake shows that $H$. spinulosus is not a surface deposit feeder.

\section{Survival}

Survival of 1 to 3 mo old juveniles seems to be lower than for subadults, and juveniles have repeatedly been reported to be more sensitive than subadults to deviations from optimal conditions in abiotic and biotic factors (Hill 1992, Elmgren et al. 2001). The reason for the high juvenile mortality in some controls is unclear. Monoporeia affinis normally shows cyclic fluctuations covering 6 to $7 \mathrm{yr}$ in the Gulf of Bothnia (Laine et al. 1997), and our own observations in the Baltic proper indicate that very high population density is often followed by dramatic density decrease at specific sites. Since $M$. affinis has comparatively high lipid content (ca. $30 \%$ ) and growth is mainly based on lipids (Lehtonen \& Andersin 1998), it is possible that decreased production of diatoms means insufficient food resources to maintain the high amphipod density resulting in suddenly impaired conditions and subsequent dramatic mortality. In some years we have observed this high mortality of field-collected amphipods both in laboratory experiments and in situ. However, this suggested impaired condition of $M$. affinis does not influence the outcome of the experiment, since mortality did not differ between treatments, but instead reflected a realistic scenario frequently occurring in situ (Aljetlawi 2003). It is possible that the field-collected juveniles had been exposed to sub-optimal conditions in the sampling area at the time of collection.

Survival of subadult Monoporeia affinis and subadult Pontoporeia femorata decreased below $2 \mathrm{mg} \mathrm{O}_{2}$ $\mathrm{l}^{-1}$, which is in accordance with findings by Johansson (1997b). Macoma balthica was most tolerant to low oxygen conditions of all species studied in our experiments. Survival after $7 \mathrm{~d}$ was $100 \%$ at $5^{\circ} \mathrm{C}$ in the SH0.8 treatment. Dries \& Theede (1974) reported 50\% survival even after $68 \mathrm{~d}$ of anoxia at $5^{\circ} \mathrm{C}$. Halicryptus spinulosus is also a species that can survive long periods of hypoxic and anoxic conditions (Weigelt \& Rumohr 1986). The reported median lethal time under anoxia is $35 \mathrm{~d}$ at $10^{\circ} \mathrm{C}$ and $120 \mathrm{~d}$ at $0^{\circ} \mathrm{C}$ (Oeschger \& Theede 1986). After severe oxygen depletion in the Kiel Bight, most macrozoobenthic species except H. spinulosus disappeared (Weigelt \& Rumohr 1986). The high survival in our short-term experiment was, thus, no surprise.

In Monoporeia affinis food intake decreased markedly at low oxygen concentrations that caused some mortality, but it seems that short-term mortality starts to increase only at even lower oxygen concentrations. Exposure to short-term hypoxia may have negative effects on growth rate and reproduction, which would affect both species and community levels. It is possible that surface-feeders surviving in low oxygen conditions, like Macoma balthica, benefit from increased amphipod mortality, since more food will be available and increased growth rate and reproduction, therefore, can be expected. However, under long-term exposure to hypoxia, decreased survival may be caused by reduced food uptake; thus, death may be due indirectly to low oxygen concentrations, as the animals starve slowly to death.

Depending on the sensitivity of the exposed animals, exposure to anoxia can be the direct cause of mortality. In the dynamic Baltic Sea ecosystem, the fluctuations in species' abundance and biomass over time can partly be explained by the combined effect of oxygen on short-term survival and long-term food intake. Animals living on the edge of areas with poor oxygen conditions can survive, but as feeding decreases, the allocation of resources to reproduction decreases, as does the allocation to the energy stores of these 'edge' animals, and finally they die.

\section{CONCLUSIONS}

Feeding changed markedly in juvenile and subadult amphipods at the lowest oxygen concentrations, but no effect was seen in Macoma balthica and Halicryptus spinulosus. Juvenile feeding increased at the lowest oxygen concentration studied $\left(3 \mathrm{mg} \mathrm{O} \mathrm{I}^{-1}\right)$, whereas feeding by the subadult Monoporeia affinis and subadult Pontoporeia femorata decreased $\left(1.6 \mathrm{mg} \mathrm{O}_{2} \mathrm{l}^{-1}\right)$.

The high uptake of radioactivity by subadult Monoporeia affinis in the C10.6 treatment is explained by $M$. affinis primarily being a surface deposit feeder, and the much lower uptake is explained by subadult Pontoporeia femorata being a subsurface deposit feeder (Byrén et al. 2002). Halicryptus spinulosus is not a surface feeder.

Reduced feeding due to sublethal oxygen concentrations might be a possible explanation for the reduction in abundance and biomass of benthic deposit feeders observed in monitoring programmes conducted in the Baltic Sea.

Acknowledgements. We thank E. Håkansson for assisting in the field and laboratory, and the staff at the Askö Laboratory for help with field collection. R. Elmgren, S. Blomqvist, E. Gorokhova, S. Hansson, Rutger Rosenberg and 2 anonymous referees gave helpful comments on the manuscript. This work was supported by MISTRA, the Foundation for Strategic Environmental Research (grant to R. Elmgren), and by SEPA, the Swedish Environmental Protection Agency (grant to B.S.). 


\section{LITERATURE CITED}

Aljetlawi AA (2003) Effects of size on growth and survival in a deposit-feeding amphipod, Monoporeia affinis in the Gulf of Bothnia (N. Baltic Sea). PhD thesis, Umeå University, Dept Ecology and Environmental Science, ISBN 91-7305-421-6

Ankar S, Sigvaldadottir E (1981) On the food composition of Halicryptus spinulosus von Siebold. Ophelia 20:45-51

Arntz WE (1978) The 'upper part' of the benthic food web: the role of macrobenthos in the western Baltic. Rapp P-V Reùn Cons Int Explor Mer 173:85-100

Brante A, Hughes RN (2001) Effect of hypoxia on the preyhandling behaviour of Carcinus maenas feeding on Mytilus edulis. Mar Ecol Prog Ser 209:301-305

Byrén L, Ejdung G, Elmgren R (2002) Comparing rate and depth of feeding in benthic deposit-feeders: a test on two amphipods, Monoporeia affinis (Lindström) and Pontoporeia femorata Kröyer. J Exp Mar Biol Ecol 281:109-121

Byrén L, Ejdung G, Elmgren R (2006) Uptake of sedimentary organic matter by the deposit-feeding Baltic amphipods Monoporeia affinis and Pontoporeia femorata. Mar Ecol Prog Ser 313:135-143

Cederwall H (1979) Diurnal oxygen consumption and activity of two Pontoporeia (Amphipoda, Crustacea) species. In: Naylor E, Hartnoll RG (eds) Cyclic phenomena in marine plants and animals. Pergamon Press, Oxford, p 309-316

Das T, Stickle WB (1993) Sensitivity of crabs Callinectes sapidus and C. similis and the gastropod Stramonita haemastoma to hypoxia and anoxia. Mar Ecol Prog Ser 98:263-274

Diaz RJ, Rosenberg R (1995) Marine benthic hypoxia: a review of its ecological effects and the behavioural responses of benthic macrofauna. Oceanogr Mar Biol Annu Rev 33: 245-303

Dries RR, Theede H (1974) Sauerstoffmangelresistenz mariner Bodenevertebraten aus der westlichen Ostsee. Mar Biol 25: 327-333

Dries RR, Theede H (1976) Stoffwechselintensität und Reservestoffabbau einiger mariner Muscheln bei herabgesetzter Sauerstoffsättigung des Mediums. Kiel Meeresforsch (Sonderh) 3:37-48

Ejdung G (1998) Behavioural responses to chemical cues of predation risk in a three-trophic-level Baltic Sea food chain. Mar Ecol Prog Ser 165:137-144

Ejdung G, Elmgren R (2001) Predation by the benthic isopod Saduria entomon on two Baltic Sea deposit-feeders, the amphipod Monoporeia affinis and the bivalve Macoma balthica. J Exp Mar Biol Ecol 266:165-179

Ejdung G, Byrén L, Elmgren R (2000) Benthic predator-prey interactions: evidence that adult Monoporeia affinis (Amphipoda) eat postlarval Macoma balthica (Bivalvia). J Exp Mar Biol Ecol 253:243-251

Elmgren R (1978) Structure and dynamics of Baltic benthos communities, with particular reference to the relationship between macro- and meiofauna. Kiel Meeresforsch (Sonderh) 4:1-22

> Elmgren R, Ejdung G, Ankar S (2001) Intraspecific food competition in the deposit-feeding benthic amphipod Monoporeia affinis-a laboratory study. Mar Ecol Prog Ser 210:185-193

Eriksson Wiklund AK, Sundelin B (2001) Impaired reproduction in the amphipods Monoporeia affinis and Pontoporeia femorata as a result of moderate hypoxia and increased temperature. Mar Ecol Prog Ser 222:131-141

> Goedkoop W, Sonesten L, Ahlgren G, Boberg M (2000) Fatty acids in profundal benthic invertebrates and their major food resources in Lake Erken, Sweden: seasonal variation and trophic indications. Can J Fish Aquat Sci 57:2267-2279
Gray JS, Wu RS, Or YY (2002) Effects of hypoxia and organic enrichment on the coastal marine environment. Mar Ecol Prog Ser 238:249-279

> Hagerman L, Uglow R (1982) Effects of hypoxia on osmotic and ionic regulation in the brown shrimp Crangon crangon (L.) from brackish water. J Exp Mar Biol Ecol 63: 93-104

Hervant F, Mathieu J, Garin D, Freminet A (1996) Behavioral, ventilatory, and metabolic responses of the hypogean amphipod Niphargus virei and the epigean isopod Asellus aquaticus to severe hypoxia and subsequent recovery. Physiol Zool 69:1277-1300

Hervant F, Mathieu J, Messana G (1997) Locomotory, ventilatory and metabolic responses of the subterranean Stenasellus virei (Crustacea: Isopoda) to severe hypoxia and subsequent recovery. CR Acad Sci 320:139-148

Hill C (1992) Interactions between year classes in the benthic amphipod Monoporeia affinis: effects on juvenile survival and growth. Oecologia 91:157-162

Hill C, Elmgren R (1987) Vertical distribution in the sediment in the co-occurring benthic amphipods Pontoporeia affinis and P. femorata. Oikos 49:221-229

Hobro R (1979) Annual phytoplankton successions in a coastal area in the northern Baltic. In: Naylor E, Hartnoll RG (eds) Cyclic phenomena in marine plants and animals. Pergamon Press, Oxford, p 3-10

Jansson BO, Dahlberg K (1999) The environmental status of the Baltic Sea in the 1940s, today, and in the future. Ambio $28: 312-319$

Johansson B (1997a) Behavioural response to gradually declining oxygen concentration by Baltic Sea macrobenthic crustaceans. Mar Biol 129:71-78

Johansson B (1997b) Tolerance of the deposit-feeding Baltic amphipods Monoporeia affinis and Pontoporeia femorata to oxygen deficiency. Mar Ecol Prog Ser 151:135-141

Karlson K, Rosenberg R, Bonsdorff E (2002) Temporal and spatial large-scale effects of eutrophication and oxygen deficiency on benthic fauna in Scandinavian and Baltic waters-a review. Oceanogr Mar Biol Annu Rev 40: 427-489

Kester DR, Duedall IW, Connors DN, Pytkovocz RM (1967) Preparation of artificial seawater. Limnol Oceanogr 12: 176-179

- Laine A, Sandler H, Andersin AB, Stigzelius J (1997) Longterm changes of macrozoobenthos in the eastern Gotland Basin and the Gulf of Finland (Baltic Sea) in relation to the hydrographical regime. J Sea Res 38:135-159

> Lehtonen K, Andersin AB (1998) Population dynamics, response to sedimentation and role in the benthic metabolism of the amphipod Monoporeia affinis in an open sea area of the northern Baltic Sea. Mar Ecol Prog Ser 168: $71-85$

Levin LA (2002) Deep-ocean life where oxygen is scarce. Am Sci 90:436-444

> Levin LA, Boesch DF, Covich A, Dahm C and others (2001) The function of marine critical transition zones and the importance of sediment biodiversity. Ecosystems (NY, Print) 4:430-451

Lockwood APM (1968) Respiration and metabolism. In: Lockwood APM (ed) Aspects of the physiology of Crustacea, Oliver and Boyd, Edinburgh, p 11-303

Lopez G, Elmgren R (1989) Feeding depths and organic absorption for the deposit-feeding benthic amphipods Pontoporeia affinis and Pontoporeia femorata. Limnol Oceanogr 34:982-991

> Maire O, Duchêne JC, Rosenberg R, de Mendonça JB Jr, Grémare A (2006) Effects of food availability on sediment 
reworking in Abra ovata and A. nitida. Mar Ecol Prog Ser 319:135-153

McMahon BR (2002) Physiological adaptation to environment. In: Holdich DM (ed) Biology of freshwater crayfish. Blackwell, Oxford, p 327-376

Normant M, Graf G, Szaniawska A (1998) Heat production in Saduria entomon (Isopoda) from the Gulf of Gdansk during an experimental exposure to anoxic conditions. Mar Biol 131:269-273

Oeschger R (1990) Long-term anaerobiosis in sublittoral marine invertebrates from the western Baltic Sea: Halicryptus spinulosus (Priapulida), Astarte borealis and Arctica islandica (Bivalvia). Mar Ecol Prog Ser 59:133-143

Oeschger R, Storey KB (1990) Regulation of glycolytic enzymes in the marine invertebrate Halicryptus spinulosus (Priapulida) during environmental anoxia and exposure to hydrogen sulfide. Mar Biol 106:261-266

Oeschger R, Theede H (1986) Untersuchungen zur LangzeitAnaerobiose bei Halicryptus spinulosus (Priapulida). Verh Dtsch Zool Ges 79:401

> Oeschger R, Peper H, Graf G, Theede H (1992) Metabolic responses of Halicryptus spinulosus (Priapulida) to reduced oxygen levels and anoxia. J Exp Mar Biol Ecol 162: $229-241$

Ólafsson EB (1986) Density dependence in suspension-feeding and deposit-feeding populations of the bivalve Macoma balthica: a field experiment. J Anim Ecol 55:517-526

Peters RH (1983) The ecological implications of body size. Cambridge University Press, Cambridge

Powilleit M, Kitlar J, Graf G (1994) Particle and fluid bioturbation caused by the priapulid worm Halicryptus spinulosus (V. Siebold). Sarsia 79:109-117

Rabalais NN, Turner R, Wiseman WJ Jr (2002) Gulf of Mexico hypoxia, A.K.A. the dead zone. Annu Rev Ecol Syst 33: 235-263

Sandberg E (1994) Does short-term oxygen depletion affect

Editorial responsibility: Anne Hershley,

Greensboro, North Carolina, USA predator-prey relationships in zoobenthos? Experiments with the isopod Saduria entomon. Mar Ecol Prog Ser 103: $73-80$

Savage C, Elmgren R, Larsson U (2002) Effects of sewagederived nutrients on an estuarine macrobenthic community. Mar Ecol Prog Ser 243:67-82

Segerstråle S (1950) The amphipods on the coast of Finlandsome facts and problems. Commentat Biol Soc Sci Fenn $14: 1-28$

Sobral P, Widdows J (1997) Influence of hypoxia and anoxia on the physiological responses of the clam Ruditapes decussatus from southern Portugal. Mar Biol 127:455-461

> Sundelin B (1983) Effects of cadmium on Pontoporeia affinis (Crustacea, Amphipoda) in laboratory soft-bottom microcosms. Mar Biol 74:203-212

> Svetlichny LS, Hubareva ES, Erkan F, Gucu AC (2000) Physiological and behavioural aspects of Calanus exinus females (Copepoda:Calanoida) during vertical migration across temperature and oxygen gradients. Mar Biol 137: 963-971

Tallqvist M (2001) Burrowing behaviour of the Baltic clam Macoma balthica: effects of sediment type, hypoxia and predator presence. Mar Ecol Prog Ser 212:183-191

Taylor E (1982) Control and co-ordination of ventilation and circulation in crustaceans: responses to hypoxia and exercise. J Exp Biol 100:289-320

> Terwilliger NB (1998) Functional adaptations of oxygentransport proteins. J Exp Biol 201:1085-1098

> Wang WX, Widdows J (1991) Physiological responses of mussel larvae Mytilus edulis to environmental hypoxia and anoxia. Mar Ecol Prog Ser 70:223-236

Weigelt M, Rumohr H (1986) Effects of wide-range oxygen depletion on benthic fauna and demersal fish in Kiel Bay 1981-1983. Kieler Meeresforsch 31:124-136

Zebe E (1991) Arthropods. In: Bryant C (ed) Metazoan life without oxygen. Chapman \& Hall, London, p 218-237

Submitted: December 27, 2007; Accepted: May 21, 2008

Proofs received from author(s): July 5, 2008 